\title{
Observations on the Anatomy of Solenostelic Ferns.
}

\author{
I. Loxsoma.
}

BY

\author{
D. T. GWYNNE-VAUGHAN, M.A. \\ Demonstrator in Botany at the University of Glasgow.
}

\section{With Plate III.}

INTRODUCTION.

W

HEN the idea of polystelic structure was first enunciated by Van Tieghem in $1886^{1}$, he introduced at the same time the word gamostely in order to distinguish that particular type of polystelic structure which he regarded as arising by the more or less extensive fusion of originally separate steles. A small number of large curved plates or even a single closed tube may be formed as a result of this supposed fusion, and in continuance of this terminology each of these vascular masses is to be called a gamostele. In the second edition of his textbook, published in I89 ${ }^{2}$, Van Tieghem offers another term, solenostely, as an alternative to gamostely, although he himself makes no further use of the suggestion, apparently preferring the original term, which he retains in all his subsequent works. Nevertheless, for the purposes of this

1 Sur la Polystélie, Ann. des Sc. Nat. (Bot.), sér. vii, tome iii.

2 Traité de Botanique (and ed.), p. I372.

[Annals of Botany, Vo1. XIV. No. LVII. March, 1901.] 
paper, so many advantages are possessed by the alternative term solenostely, that, instead of employing the older word, retained by Van Tieghem, it becomes clearly advisable to return to the rejected term. The most important of these advantages is the complete freedom from that suggestion of fusion that is implied by the word gamostely; and since, for the present at any rate, it is intended to use the term in a descriptive sense only, as a more convenient expression for the closed tubular bundle of De Bary ${ }^{1}$, the absence of this idea is a very valuable property of the word. Indeed, it becomes an advantage of critical importance when it is considered that evidence is forthcoming which renders it extremely probable that in most cases no process of fusion whatever has anything to do with the production of a solenostele. As regards the Ferns in particular, it may be safely stated that in most cases the solenostelic arrangement of the vascular tissue is more primitive than the polystelic, since it has been shown in several Ferns that the final polystelic condition is preceded by a solenostelic stage at one time or another in the life-history of the individual plant. In such a plant the solenostele cannot be described as arising from the fusion of polystelic steles, but rather the polystelic state as brought about by the splitting up of a solenostelic ring. However, it is not to be inferred from this statement that no cases of real gamostely (in Van Tieghem's sense) exist at all; on the contrary, it does not seem by any means unlikely that such cases should occur, even among the Ferns themselves, and if future research should bring such a one to light, the word gamostely remains ready to hand as a term most suitable for the occasion. The fact, however, remains that gamostely, as at present applied, is a misleading term, because the structure indicated by it has been shown to be susceptible of an explanation exactly opposite to that implied by the term itself.

Again, the distinction between solenostely (gamostely) as defined by Van Tieghem, and dialystely (polystely with free

\footnotetext{
1 Comp. Anat. (Engl. ed.), p. 284, 1884.
} 
unfused steles) is merely one of degree, cases often arising in which it is no easy matter to decide which is the more suitable expression to use. Therefore, since the utility of a descriptive term will be the greater the more it is susceptible of accurate delimitation, it will be advisable to state at once that a solenostelic stem, as understood in this paper, may be defined as one in which the vascular tissue is arranged in a single hollow cylinder with phloem and phloeoterma on either side, the complete continuity of which is interrupted only by the departure of the leaf-traces; the gaps thus produced being closed up in the internode above before the departure of the next leaf-trace.

Whilst engaged in the preparation of this paper I was privileged to see an advanced copy of an exceedingly interesting and suggestive paper by Dr. Jeffrey ${ }^{1}$, in which Van Tieghem's terminology is discussed at some length, and precisely the same opinion regarding the misleading nature of the term gamostely is arrived at (1.c., p. 605). Jeffrey has proposed an altogether new terminology based upon the word siphonostele, which, I take it, may be defined as a fibro-vascular tube interrupted by lacunae opposite the points of departure of branches, or of leaf-traces (1.c., p. 632). Although I am not yet prepared to accept all the phylogenetic relationships that are to be inferred from Jeffrey's system, in particular that relating to the Phanerogamic medullated monostele, yet many of the distinctions made are peculiarly fortunate, and coincide with structural features of crucial importance. In any case, no specific term is supplied for the particular vascular arrangement defined above as solenostelic, to which I believe it will be found convenient, in describing the anatomy of the Ferns, to give a name of its own. According to Jeffrey's terminology, solenostely would be regarded as a special type of amphiphloic phyllosiphony.

Although the solenostelic type of vascular structure is in general one of very rare occurrence, still a fair number of

1 The Morphology of the central Cylinder in the Angiosperms; Transactions of the Canadian Institute, vol. vi, p. 599. 
excellent examples are to be found among the Ferns, more frequently perhaps than among any other class of plants. Finding that these plants have not yet been closely investigated with reference to this particular character, I have been occupied for some time in examining all those species presenting indications of solenostely that I have been able to obtain. In the course of these investigations some alcoholmaterial of Loxsoma Cunninghamii, R. Br., was placed at my disposal by Professor Bower, to whom it had been sent by Messrs. Thompson and Cheeseman from New Zealand.

Hardly anything has hitherto been written upon the anatomy of this rare and interesting Fern, and since it obtains additional importance both on account of its isolated systematic position and of its limited distribution, it would seem to deserve a somewhat detailed anatomical description. I have therefore ventured to devote a special part of this paper to that purpose, reserving for a second part the less detailed descriptions, and the more general results that may arise from the investigation of the other solenostelic Ferns that I have been able to examine.

The history of the nomenclature of Loxsoma, and of the various opinions that have been held regarding its systematic position, has been summarized by Professor Bower ${ }^{1}$ in his recent paper on the Leptosporangiate Ferns, so that by way of recapitulation it is only necessary to mention the few references to the anatomy that have been found in the literature. The first of these is made by Mettenius ${ }^{2}$ in 1865 , and is only a casual reference to the anatomy of the stem of Loxsoma as differing from that of the rest of the Hymenophyllaceae (with which he includes it) on account of its 'closed vascular bundle tube.' He also notes that the root is diarch, and mentions a few facts relating to the venation. Russow ${ }^{3}$,

1 The Morphology of Spore-producing Members; iv. The Leptosporangiate Ferns; Phil. Trans., vol. cxcii, p. 47, 1899.

2 Über die Hymenophyllaceae, Abhandl. d. K. Sächs. Gesellsch. d. Wiss., Bd. vii, pp. $4^{1} 5$ and $4^{1} 8$.

3 Vergl. Untersuch. d. Leitbündel-Krypt., Mém. de l'Acad. Imp. de St. Pétersbourg, sér. vii, tome xix, p. $80,187 \mathrm{I}$. 
later on, does no more than quote Mettenius, and then compare the structure of the vascular system to that of Marsilea. No mention is made at all of the anatomy of Loxsoma by Prantl in his paper on the Hymenophyllaceae, and De Bary (1.c. p. 284) only refers again to Mettenius, at the same time regretting the lack of information concerning the nature of the foliar gaps in the tubular bundle. Finally, Giesenhagen ${ }^{1}$ confuses the correct opinion hitherto held regarding the vascular system, by speaking of it as a central collateral or concentric bundle; he also refers incorrectly to the structure of the cortex.

As regards the external morphology little additional information can be given. The rhizome is cylindrical and fairly stout $\left(5^{-6} \mathrm{~mm}\right.$.). It creeps upon the surface of the soil, bearing erect leaves some two feet high, at intervals of about an inch. The leaves are situated on the upper surface of the stem, apparently in a single row, but alternating slightly on either side of the median line. They arise in acropetal succession. The stem is said to branch, but my specimens did not furnish an example. There are no localized points of departure for the roots, which arise irregularly upon the under surface and sides of the rhizome, both at the nodes, and also along the internodes. The leaves are highly dissected, and perfectly smooth and glabrous. On the stem and the base of the petiole (which is not articulated onto the stem) are a number of slight emergences which form the bases of awl-shaped structures more fitly described as hairs than as paleae. They are three or four cells thick at their base, but terminate in a single cell-row $\left(5^{-12}\right)$, the last cell of all being conically pointed. The walls are but little thickened and are coloured brown.

\section{THE STEM.}

In a transverse section taken through an internode in a fully differentiated region of the stem, the vascular system is easily distinguished by the naked eye as a thin, perfectly

\footnotetext{
1 Die Hymenophyllaceen, Flora, 1890.
} 
continuous ring of a white or grey colour, situated in the midst of the yellowish-brown ground-tissue at a distance from the centre of about a third of the radius (Plate III, Fig. I). The ground-tissue is almost entirely composed of vertically elongated cells with square or bluntly pointed ends. The cellwalls are well thickened, with numerous round simple or slightly bordered pits, and are impregnated by some colouring substance to which is due the general brown appearance of the section. The cells of the epidermis, though less elongated vertically, do not differ from those of the ground-tissue in the structure of their walls or in the colour. Sclerenchymatous cells such as these compose the whole of the groundtissue of the stem, with the exception of a few layers of parenchyma with thin, colourless, and unlignified walls, intervening between the endodermis and the sclerenchyma on either side of the solenostele (Fig. 2, $a, a^{\prime}$ ); and again of a few similar parenchyma-cells that are found irregularly scattered in small groups and strands in the midst of the sclerenchyma itself. These small parenchymatous islets in the sclerenchyma only occur in the neighbourhood of the solenostele, becoming fewer the farther away from it on either side. In longitudinal section it is seen that the cells of which they are composed are much shorter than those of the thickwalled ground-tissue, that they have rounded outlines forming conspicuous intercellular spaces, and that they are arranged in vertical rows of various lengths, which appear to arise, in the apical region, by rapid and long-continued division in certain cells, while the rest grow on without further division. As regards the general sclerenchyma the cells have thinner walls and wider lumens at the very centre of the stem, and in the median region of the cortical ground-tissue (that lying without the solenostelic ring) than elsewhere (Fig. I). The occurrence of these scattered islets of parenchyma among the sclerotic general ground-tissue of the stem is an interesting peculiarity, and I believe one of very rare occurrence among the Ferns, the only other instances which I have hitherto come across being in the stems of Dicksonia apiifolia, Hk., 


\section{Anatomy of Solenostelic Ferns: I. Loxsoma. 77}

and $D$. cicutaria, Sw., two plants which will be later on compared with Loxsoma on other grounds also. The rows or strands of thin-walled cells, filled with a brown resinous tannincontaining substance, which are stated by Russow ${ }^{1}$ to be scattered among the starch-bearing sclerotic cells of the pith and inner portion of the cortex in the rhizome of certain Marsileas ( $M$. salvatrix, $M$. elata), may perhaps be regarded as somewhat similar structures.

In Loxsoma the distinction between these islets and the rest of the ground-tissue is well maintained in regions near the apex, even before the cells of the latter have thickened their walls ; because, while the cells of the general ground-tissue are densely filled with a very finely granular almost homo. geneous substance, those of the islets have scanty and coarsely granular contents. In the older parts of the rhizome small roundish or oval starch grains appear in the thick-walled cells, but not in the thin-walled cells that form the islets, although this may not hold true for all seasons of the year.

Intercellular spaces are present both in the central and the inner cortical ground-tissue, especially between the cells with thin walls. The external surfaces of the cell-walls, where they do not border upon each other, are beset with numerous delicate little rods which project into the intercellular spaces. They usually end freely in the cavity, and then they are often slightly swollen and curved at the tip; sometimes they reach right across the intercellular space and are attached to the cell-wall opposite; more rarely they anastomose with one another, or appear to branch. They are composed of some perfectly homogeneous, highly refractive substance, usually colourless, but sometimes in the older parts of the stem faint yellow. They are certainly not composed of ordinary cellulose because they are not turned blue when treated with iodine and sulphuric acid, but swell slightly and become faint yellow: treated with concentrated sulphuric acid they are dissolved, but more slowly than the rest of the cell-wall. Intercellular rodlets of this kind were first discovered by

\footnotetext{
1 Loc. cit., p. Io.
} 
Luerssen ${ }^{1}$ in Kaulfussia cicutifolia and other Marattiaceae, and they have since been described in the Ophioglossaceae, and in a number of Cyatheaceae and Polypodiaceae ${ }^{2}$.

The annular stele is limited on either side by a very distinct endodermis, consisting of vertically elongated square-ended cells, easily distinguished from the rest of the ground-tissue by reason of their very dense grey-coloured contents (Figs. 2 and $\left.3, e, e^{\prime}\right)$. Some of the cells of the endodermis differ in appearance from the rest, owing to the more coarsely granular nature of their contents, which are also impregnated with tannin. No undulations were observed on the radial longitudinal walls, but they are more or less cutinized, especially at the angles. The pericycle forms a continuous zone within the endodermis on either side of the solenostele; on the outer side, it consists of three to four layers of slightly elongated comparatively wide-lumened cells with finely pitted walls, the terminal walls being transverse or slightly oblique ; on the inner side of the solenostele it is less developed, two or three layers only being present. In sections near the apex, the cells of the pericycle are seen to be superposed upon each other and upon those of the endodermis with considerable regularity, and, allowance being made for displacement due to growth and subsequent division, there is but little doubt that they all originated from the subdivision of a single cell-layer of the ground-tissue, and that therefore the pericycle is not a true but a false one (cf. Fig. 3).

The phloem, again, forms a continuous zone on either side of the solenostele, and, like the pericycle, is somewhat greater in quantity on the outer side than on the inner (Figs. 2 and 3 , $p h$ and $\left.p h^{\prime}\right)$. It consists of sieve-tubes and phloem-parenchyma. The sieve-tubes have their pores aggregated into definite areas, the sieve-plates, which are present on both the longitudinal and transverse walls; further, the sieve-plates, as in the Cyatheaceae, are so numerous and occupy so much space that the thicker portions of the wall separating them

1 Über den Bau und die Entwickel. der Gefässkrypt., Bot. Zeit., I873, p. 640.

${ }^{2}$ Cf. De Bary, Comp. Anat. (Engl. ed.), p. I I8. 
from each other are reduced to such an extent that they form a coarse network only, the meshes of which are occupied by the sieve-plates themselves. Those elements of the phloem furthest away from the xylem on either side of the solenostele are very narrow, angular and flattened, with thick and glistening walls ; in older regions almost disorganized. They constitute the protophloem, which is very clearly to be distinguished on either side of the solenostele. The central portion of the stelic ring is occupied by the xylem, which consists of scalariform tracheides with a few cells of intervening parenchyma; a layer of the latter also surrounds the xylem-strand, separating it from the phloem on both sides. The tracheides of the xylem increase in size from without towards the centre of the rhizome (Fig. 2), the smallest elements being on the outside. In sections near the apex, where the xylem is not yet fully developed, it may be seen that the smallest tracheides at the external periphery of the strand are the first to be differentiated (Fig. 3, prx), and it is especially to be observed that they are not collected into definite localized groups, but are fairly evenly distributed all round the external periphery. These first-formed elements are all scalariform tracheides; even after most careful research I have failed to discover any annular, reticulate, or spiral elements whatever in the stem, except on the upper surface just at the point of insertion of a leaf-trace, and these clearly are to be considered in relation to the latter. It is true that these first-formed elements of the xylem differ from typical protoxylem both in distribution and structure, and that they are only to be distinguished from the rest of the strand by their smaller size and early development, yet I think it is permissible to state that the protoxylem proper to the stem in Loxsoma consists of narrow scalariform tracheides evenly distributed around the external periphery of the xylem-ring. The walls of the scalariform tracheides of Loxsoma, in common with those of other Ferns and also of Marsilea ${ }^{1}$, when treated with caustic potash or any other macerating reagent, partially dissolve, in such a manner as to

${ }^{1}$ Cf. Russow, Vergl. Untersuch., loc. cit. 
split up along a spiral line, the spiral band thus formed being several bars of thickening in breadth (Fig. 9).

Attempts were made to obtain microtome sections of the stem-apex, but the material was not sufficiently well preserved to give good results, and the details of the apical development could not be followed. The termination of the stem is broad and flat, and from this the extreme apex arises rather abruptly as a small cone terminated by an apical cell. The solenostele was clearly delimited from the ground-tissue on both sides up to a point very near the apex, but I was unable to decide whether the lines of delimitation coincided with the first two tangential divisions in the apical segments, as stated for Ferns by Van Tieghem ${ }^{1}$, or not. One point, however, came out with sufficient clearness regarding the origin of the so-called pericycle, which certainly arises from centripetal divisions (i. e. towards the centre of the solenostele) in a layer of cells which also gives rise to the endodermis. This holds good for both the internal and the external pericycle. In Loxsoma, therefore, the phloeoterma is not coincident with the endodermis, but is to be found in the innermost layer of the pericycle bordering upon the phloem.

\section{THE ROOT.}

The structure of the root is essentially that of a typical Fern. There is a slender diarch xylem-plate, the protoxylems of which abut directly on the pericycle, which is one, or in places two, layers thick. Protophloem and phloem are very distinct, and the latter is separated from the xylem by a layer of parenchyma. The endodermis is well marked, and similar to that in the stem. The cortex consists of four or five layers of cells which increase in size from the endodermis outwards; their walls are somewhat thickened and coloured brown. The cells of the suberized layer are radially elongated with especially thick walls; they usually remain as the outer limit of the root, the piliferous layer being early destroyed. The

\footnotetext{
1 Traité de Botanique (2nd ed.), p. 774.
} 


\section{Anatomy of Solenostelic Ferns: I. Loxsoma. $8 \mathrm{I}$}

root-steles arise from the under-surface and sides of the solenostele of the rhizome, and the long axes of their diarch xylem-plates are so arranged that they are tangential to the solenostele in a transverse plane. The root-steles pass out in a very slightly oblique direction towards the apex.

\section{The Petiole.}

The only points at which the perfect continuity of the closed solenostele is interrupted are the points of insertion of the leaf-traces. At each node the departure of a vascular strand to supply the leaf removes a portion of the vascular ring bodily from the stem, leaving a gap through which the parenchyma and sclerenchyma of the ground-tissue lying within the vascular ring communicate with the corresponding tissues lying without it, while at the same time the internal endodermis, pericycle, and phloem become continuous with the external, around the margins of the gap. The leaf-gap thus formed persists for some little distance $(6-8 \mathrm{~mm}$.) into the internode above, but gradually becomes closed up again. The manner in which the leaf-trace actually arises from the solenostele of the stem was ascertained by the comparison of a number of consecutive transverse sections taken through a node, and the conclusion confirmed by rough dissections. As a result, Fig. 4 was drawn as the representation of the form taken up by the vascular system of the rhizome at the nodes, and it is hoped that a reference to it will facilitate further description. It is seen in the diagram that the portion of the vascular system of the stem destined to pass off as a leaf-trace is clearly indicated for a short time previous to its departure as a protuberance on the upper side of the solenostele, and a reference to transverse sections shows that this leaf-trace portion rapidly diminishes in thickness as the point of departure is approached. The drawing is further intended to show that the leaf-trace (which has the form of a trough, or in transverse section that of a horseshoe) is seated upon the vascular tube of the stem almost in the 
middle line, with its convexity directed towards the base of the stem and its concavity towards the apex.

The transverse section of the free petiole is approximately oval, and its vascular strand, which lies towards the centre, is curved into the form of a horseshoe with the concavity directed adaxially (Fig. 5). The limbs of the horseshoe are enlarged towards their extremities; it varies in degree of curvature according to the level in the petiole at which the section is taken, the limbs being more widely separated and the whole strand less curved towards the top of the petiole. Towards the base of the petiole the ground-tissue is exactly like that of the stem, being entirely sclerenchymatous, with the exception of two or three layers of parenchyma immediately surrounding the vascular strand, and a few similar elements scattered amidst the more central sclerenchyma. However, at a point higher up, the brown sclerenchyma at the periphery of the petiole becomes changed into a hypodermal zone of elongated finely-pointed fibres with thick colourless walls and slit-like pits, while all the rest of the ground-tissue gradually becomes thin-walled and parenchymatous. The brown sclerenchyma persists longest within the concavity of the horseshoe, and along its flanks. At rare intervals, the dense sclerenchyma occupying the periphery of the petiole is interrupted by short tracts of loosely packed cells visible on the outside as short grey streaks. In longitudinal section it is seen that these tracts consist of elongated sausage-shaped cells, with rounded ends whose longitudinal walls are not in close contact all along their length, but separate from each other at intervals, so that a number of intercellular spaces of different sizes appear between them. These intercellular spaces give the tissue a distinctive appearance both in longitudinal and transverse section, although in the thickness of their walls and in other respects its cells closely resemble those of the rest of the ground-tissue. The few stomata that are to be found upon the petiole are localized above these tracts of tissue. The petiolar parenchyma in a very large number of Ferns is 


\section{Anatomy of Solenostelic Ferns: I. Loxsoma. 83}

interrupted by similar tracts of spongy air-filled tissue ; most frequently it occurs as a single continuous line on either side of the petiole; often the line is more or less interrupted, or indeed, as in Loxsoma itself, completely broken up, so that this tissue is represented by a number of short streaks which are not even arranged in the same straight line, although they are still aggregated towards the sides of the petiole. The very general distribution among the Filicales of this tissue, which might be regarded as representing modified traces of a mesophyll decurrent along the sides of the petiole, is a very significant phenomenon in reference to the view advanced by Professor Bower ${ }^{1}$ concerning the leaf of the Ferns, which he regards as a rachis or phyllopodium, fundamentally winged along its whole length.

The xylem occupies the centre of the vascular strand of the petiole, the outline of which it accurately follows, except in the enlarged ends of the flanks of the horseshoe, where the xylem-strand is bent on itself, forming a hook which is curved inwards and encloses a small bay between itself and the rest of the xylem (Figs. 5 and $6, h k$ ). The phloem surrounds the xylem completely but not evenly, being in greatest quantity on both sides of the flanks, while on the median concave region of the horseshoe it is very scanty.

The protophloem, with its flattened angular elements and swollen walls, is well marked, especially on the flanks, but it is entirely absent in the median concave region (Fig. 5, pph). The pericycle consists of two or three layers, except in the median region, where only one is present; on the outside of the flanks of the horseshoe its cells are considerably larger than elsewhere. In examining the petiolar meristele of Loxsoma attention is at once attracted to the presence of a number of sclerosed fibrous elements situated in close proximity to the periphery of the xylem, such elements being of very rare occurrence in the vascular strands of Ferns. These

1 Comp. Morph. of the leaf of the Vasc. Crypt.; Phil. Trans., vol. clxxv, I884, p. 606 . 
sclerotic fibres are found in greatest quantity at the inner side of the phloem along the flanks of the horseshoe, and especially in the bays formed by the hooked ends of the xylem. One or two layers of the same accompany the concave internal surface of the xylem-strand, entirely replacing the phloem in the median region, and a few also occur on the external convex surface, forming an interrupted layer between the xylem and the phloem (Figs. 5 and 6, sc.t.). Fibrous elements, almost identical in position and appearance with those of Loxsoma, have been carefully described in the petiole of Aneimia Phyllitidis by Prantl ${ }^{1}$, who regards them as belonging to the phloem. Poirault ${ }^{2}$ goes further; for he considers some very similar elements he observed in the petioles of certain Gleichenias actually to represent sievetubes which have undergone sclerosis. Evidence is not wanting which would lead to a similar conclusion with respect to the fibrous elements in Loxsoma. In the first place, the position that they occupy in the meristele relative to the other tissues is precisely that of sieve-tubes, and, wherever they occur in mass, thin-walled parenchyma-cells are scattered amongst them, which may be regarded as representing the phloemparenchyma (Fig. 6, pa). Again, towards the base of the petiole they gradually decrease in number (those in the bays of the hooks persisting longest), until at the point where the leaf-trace enters the tissue of the stem they disappear altogether, their place being progressively taken up by undoubted sieve-tubes. They are usually separated from the xylem by a layer of thin-walled parenchyma, but occasionally are found in direct contact with a tracheide (Fig. 6, at +). This, however, does not affect our comparing them with sieve-tubes, because the latter are also sometimes found in the same position, both in Loxsoma and in other Ferns.

Moreover, as seen in Loxsoma, these fibrous elements closely

${ }^{1}$ Untersuch. z. Morph. d. Gefässkrypt., Heft ii, Schizaeaceen, p. 28 (Leipzig, I88I).

${ }^{2}$ Recherches Anat. sur les Crypt. Vasc., Ann. Sc. Nat., sér. vii, tome xviii, p. I90, and Fig. I8, 1893 . 
resemble sieve-tubes in their structural details, being very elongated and tubular, and arranged more or less in series with very oblique terminal walls. The walls are greatly thickened and more or less lignified, but even when strongly so they are easily distinguished from the tracheides by the rounded inner contour of their lumen (Fig. 6). Two fairly distinct layers of thickening have been deposited upon the middle lamella. A number of round or elliptical simple pits are scattered over the walls (Fig. IO), and in immature stages (especially on the terminal walls) they are so numerous and of such a size that they give the impression of a coarse reticulation, reminding one strongly of the sieve-tubes themselves. They never appear to be quite empty, but have much denser contents than the sieve-tubes, and nuclei are frequently to be observed in them. It would seem, therefore, that both their distribution and their structure would most readily be explained if they were regarded as elements of the phloem originally designed for sieve-tubes, but which, in the course of their development, have thickened and lignified their walls to such an extent that the areas which should have become sieveplates have become simple pits, and the whole element more closely resembles a fibre than a sieve-tube. It is not implied, of course, that they were all at one time actually functional sieve-tubes. Further support for this point of view may be drawn from the fact that a number of elongated elements with thick two-layered but unlignified walls, occupying precisely the same position in the petiolar meristele as do the fibrous elements in Loxsoma, may be found in many Microlepias (Davallia platyphylla), and Dennstaedtias (Dicksonia punctiloba), where they can only be interpreted as representing sieve-tubes.

Although the above explanation seems highly probable for the particular plants in question, yet it certainly is not safe to apply it to all the other cases in which fibrous elements have been found in the petiolar meristeles of Ferns. However, it seems to account satisfactorily for the cases of Lygodium, Schizaea, and Aneimia mentioned by Prantl (1.c.), and also 
for that of Matonia pectinata ${ }^{1}$. On the other hand, in Trichomanes Prieurii, where these fibres were first discovered by Mettenius (1.c.), all the sclerotic elements can hardly be regarded as sclerosed sieve-tubes, because, as I have seen, although some are elongated and pointed, resembling those in Loxsoma, there are also others which are relatively short and square-ended; here, perhaps, both constituents of the phloem, sieve-tubes, and parenchyma are implicated in the sclerosis. Finally, a very puzzling case is described by Thomae $^{2}$ in the petiole of Adiantum trapeziforme, var. pentadactylon, where the fibrous elements are found not only at the margin of the xylem-strand, but also intermingled among the tracheides themselves. The most obvious suggestion seems to be that the xylem-parenchyma has become sclerotic and fibrous.

The xylem, apart from its first-formed elements, consists of scalariform tracheides, which upon treatment with caustic potash behave in the same way as those in the stem. The largest tracheides are found on the flanks of the xylem-strand, and the smallest in the neighbourhood of the protoxylemgroups. The protoxylem consists of narrow elements exhibiting beautiful spiral and angular thickenings, and is situated on the internal adaxial surface of the xylem-strand, towards the concavity of the horseshoe; it may therefore be regarded as endarch (Figs. 6 and 8, prx ). The number of groups varies according to the petiole, and in the same petiole according to the level at which the section is taken, becoming fewer towards the top of the rachis. Generally speaking, there are two or three groups in the bay of each hook, and from two to six along the dorsal-curved portion of the strand. These endarch protoxylems, although perfectly clear and distinct in all parts of the free petiole, gradually become less definite when the petiolar meristele enters the tissues of the stem. Shortly after the leaf-trace has become completely

1 Seward, Struct. and Affin. of Matonia pectinata, Phil. Trans., B., vol. cxci, I899, p. I 83 .

2 Blattstiele der Farne, Prings. Jahrb., Bd. xvii, I886, p. I 29. 
continuous with the upper surface of the solenostele, they disappear altogether without at any time coming into relation with the scalariform protoxylem-elements that line the external border of the lower part of the solenostele.

In the leaf-trace, therefore, the xylem is developed centrifugally from definite and typical protoxylem-groups. On the other hand, it has been shown that in the stem the development of the xylem is not related to the leaf-trace protoxylems decurrent in the stem, nor to any other definitely localized groups; neither are there any elements present in the stem which exhibit the characteristics typical for protoxylem. Since the whole mass of xylem in the stem cannot well be regarded as metaxylem (primary xylem other than protoxylem), I find it necessary to accept the alternative, and to recognize in Loxsoma two kinds of protoxylem differing in structure and in disposition; one peculiar to the stem, and the other to the leaf. Particular attention has been drawn to this distinction because it may prove a factor of considerable importance in the estimation of the influence exerted by the anatomy of the leaf upon that of the stem, in cases where the former is the predominant member of the plant, a subject which does not seem to have attracted the attention it deserves.

The xylem is almost entirely free from parenchyma scattered among its tracheides, but at the same time the whole strand is surrounded by a well-defined layer of cells exactly similar to those of xylem-parenchyma. However, the cells of this xylem-sheath (Fig. 6, x. sh) are not all alike, for those in the neighbourhood of the protoxylem-groups undergo such profound and peculiar modifications that they have been considered to be a new kind of tissue. The cells at these points become greatly enlarged by growing out into the space left vacant by the disintegration of the protoxylem-elements; their walls, which are considerably thickened and sometimes even lignified, are thrown into a number of deep irregular folds or pleats, especially on the side facing the protoxylem (Fig. I I $c p$ ). They are covered by a number of large simple pits, often to such an extent that they appear to be coarsely 
reticulated. They contain a fair amount of protoplasm and a conspicuous nucleus. Cells somewhat similar to these were first mentioned by Dippel ${ }^{1}$ in Osmunda and Cyathea; he regards them as reservoirs for bye-products such as resin, tannin, \&c., but in Loxsoma no trace of these substances is to be detected. The tissue described by Russow ${ }^{3}$ in Marsilea under the name of cavity-parenchyma (Lückenparenchym), and again by Thomae (1.c.) in Angiopteris and Cyathea under the title of 'Stumpfzellstränge,' is almost identical with that in Loxsoma. Thomae also states that the papillae may become cut off by walls from their mother-cells, on which account he compares this to a case of thylosis. Other examples have recently been given by Seward in Matonia pectinata (1.c.), and by Farmer $^{3}$ in Helminthostachys; indeed it has been mentioned by various observers as occurring in all the main families of Ferns, although the exact limits of its distribution are yet to be determined.

Towards the top of the petiole the vascular strand, although still resembling a horseshoe, is markedly different from the form already described. Taking it, for instance, at a point just below the insertion of the lowest branches of the leaf (Fig. $7, b$ ), it is seen that the flanks of the horseshoe are much wider apart from each other, and that its concavity is more shallow; in fact, the whole meristele appears to be somewhat flattened out. The departure of the vascular strands for the successive branches, which are nipped off from the ends of the arms of the meristele, does not materially alter its form, although causing it to decrease considerably in size. At the same time, however, the hooks at the ends of the xylem-curve gradually disappear, and the protoxylemgroups become fewer in number until three only are left; one at the end of each arm and one in the median region of the curved xylem (Fig. 7, c). From now onwards, this median protoxylem sinks further and further away from the

1 Das Mikroskop, Theil ii, p. 20I, Fig. 100, I867.

${ }^{2}$ Loc. cit., pp. 6 and IoI, and Taf. ii, Fig. I3.

Ann. Bot., vol, xii, no. 5I, p. 439, I899. 
adaxial surface of the meristele, until it comes to occupy the bottom of a deep bay between the arms of the xylem, which for some time have been gradually approaching each other until they are now almost in contact. At length, therefore, owing to its diminished size, and to the flatteningout of its formerly concave side, the form of the meristele has changed by degrees from that of a horseshoe to that of an equilateral triangle with rounded angles and convex sides, the adaxial side being slightly indented at the centre (Fig. 7, $d$, and Fig. 8). Nevertheless, an indication of the form it originally possessed is still to be perceived in the curve that is retained by the xylem-strand, even when the outline of the meristele itself has become elliptic. While these changes are progressing the cavity-parenchyma becomes less and less distinct, disappearing altogether before the meristele becomes elliptic. The sclerosed sieve-tubes, on the other hand, are still to be observed in considerable quantity (Fig. 8), and continue to persist even in the small veins of the lamina itself. The vascular strands of the lateral branches of the leaf pass through exactly the same changes until the ultimate ramifications of the veins in the foliar segments are reached: there they exhibit a perfectly collateral structure, the phloem being confined to the abaxial side of the xylem, at the adaxial extremity of which is situated a single protoxylem-group (Fig. $7, e$ ). Although the mesophyll of the lamina is of considerable thickness, no palisade arrangement of the cells is to be found in it. On the contrary, they are all arranged in a loose spongy manner with numerous intercellular spaces, which, however, are particularly large towards the under surface of the leaf. The cell-walls limiting these intercellular spaces are closely beset with those intercellular rodlets already described in the stem. The veins in the lamina are connected to both the upper and the lower surfaces by stout strands of sclerenchyma after the manner of girders, even the epidermal cells overlying these veins are more or less thickened and elongated in the direction of their course. The cells of the general epidermis 
are very irregular in shape, with beautifully undulated outlines. There are numerous stomata on the under-surface of the leaf, which are overtopped by the neighbouring epidermal cells in such a manner that the outer walls of the guard-cells are at the level of the inner walls of the cells of the general epidermis (Fig. I2). The external longitudinal ridges of the guard-cells are well developed and highly cutinized; but the internal are absent, although the corresponding region of the wall becomes cutinized. I was unable to ascertain the way in which the stomata were developed owing to absence of a sufficiently young leaf.

\section{General Considerations.}

In seeking to determine relationships between Loxsoma and the other Ferns, using the anatomy as a guide, I venture to regard the solenostely of the stem and the peculiar horseshoe shape of the petiolar meristele as characters of primary importance, and of considerable reliability. Judging from this point of view, it would appear that the nearest allies to Loxsoma are to be sought for among those more primitive Cyatheaceae and Polypodiaceae that are included, together with Loxsoma itself, in Bower's proposed sub-order Gradatae ${ }^{1}$. More especially is it related to certain species of Dennstaedtia and Microlepia (given by Hooker as sections of the genera Dicksonia and Davallia respectively). It is difficult to be more precise upon this point at present, because neither of these two sections, as at present constituted, are altogether homogeneous in their anatomical aspect; at least, so far as I have been hitherto able to ascertain. Nevertheless, the majority possess a typically solenostelic vascular system, and a hippocrepiform petiolar meristele, just as in Loxsoma. As regards minor detail, in most of the species of both sections the protoxylems in the petiole are bordered by cavityparenchyma, and elements resembling the sclerosed sieve-tubes

1 The Morphology of Spore-producing Members; iv. The Leptosporangiate Ferns (loc. cit.). 
are also present. In many cases also, the cells bounding the intercellular spaces of the mesophyll are beset with the small rod-like structures described in Loxsoma. If it is necessary to select any particular species for still closer comparison, Dicksonia apiiffolia, Hk. (Dennstaedtia), and D. cicutaria, Sw. may be referred to as perhaps most suitable for the purpose. In the first place, these are the only two Ferns that I am as yet aware of, besides Loxsoma, in which the protoxylemelements of the stem are all scalariform, and not aggregated into definite groups, but evenly distributed around its external periphery. Further, the small islets of parenchyma scattered amongst the sclerenchymatous ground-tissue, that form so characteristic a feature of the stem in Loxsoma, are also to be found in these two Dicksonias, with the same little rodlets projecting into their intercellular spaces. Cavity-parenchyma is present in the hippocrepiform petiolar meristele of Dicksonia apiifolia, and the sieve-tubes situated in the bays of the hooks of the xylem-strands have especially thick walls although they remain unlignified. Whether the petiole of Dicksonia cicutaria presents the same structure I did not ascertain, because my material was accidentally lost, and I have not been able to replace it.

The affinity thus brought to light between Loxsoma and the Dennstaedtiinae is in no wise discountenanced by comparisons which may be drawn from the morphology of the sorus and sporangia. For Professor Bower (1. c.) has shown that in this respect also a number of important characters are held in common by them both; such as the marginal position of the receptacle, the position and form of the indusium, the basipetal succession of the sporangia, the obliquity of the annulus, and the relatively low output of spores (64). It must be borne in mind, however, that the consideration of the sorus and the sporangium also indicates affinities as close, or even closer, to the Gleicheniaceae and Hymenophyllaceae. It is true that suggestive parallels may be drawn between the anatomy of Loxsoma and that of certain members of these families, but it seems to me that 
they are of too speculative a nature to compete with the more pronounced relationship between it and the Dennstaedtiinae.

To begin with the Gleicheniaceae. No case of simple solenostely is known in this family, the nearest approach among allied groups being the highly complex and remarkable vascular arrangement recently described by Seward (1. c.) in Matonia pectinata, R. Br., the explanation of which I am inclined to seek in the profound modification of some more simple solenostelic ancestor. It is interesting to discover that the form of the petiolar meristele of Matonia is a slight modification of the horseshoe, as indeed is also the case in Gleichenia itself, where the arms of the horseshoe are curved inwards to such an extent that they meet together in the median line, thus enclosing a small mass of sclerenchymatous ground tissue in the centre of the horseshoe. However, at one level or another in the petiole of Gleichenia dichotoma, generally near the base, I have found that the arms of the horseshoe separate from one another so that the enclosed ground-tissue becomes continuous with that outside the meristele; thus the hippocrepiform nature of the meristele becomes quite clear. It should be mentioned that both sclerosed sieve-tubes and cavity-parenchyma are to be found in $G$. dichotoma.

As regards the Hymenophyllaceae, the universal occurrence in the stem of a solid central cylinder clearly places them anatomically much farther away from Loxsoma than are the Cyatheaceae, and this estrangement is deepened by the plentiful display of stomata and intercellular spaces in the lamina of the leaf of Loxsoma, which are never to be found in the Hymenophyllaceae, not even when the lamina is several layers thick, as in Trichomanes reniforme. For all that, there are several points that suggest a certain relationship, although it may be a somewhat distant one. It is especially in the vascular strand of the petiole that these points are to be sought; for, although the outline of the vascular strand as a whole is, in most of the stouter species, oval or roughly triangular, yet I believe it possible to 
recognize indications of a horseshoe design in the more or less curved form of the xylem-strand. This possibility had already suggested itself to me before I had the opportunity of reading the interesting paper recently published by Boodle upon the anatomy of this order ${ }^{1}$. He there describes a type of petiole, previously unknown to me, which goes far to bridge over the gap that existed between the petiolar strands of the Hymenophyllaceae and the hippocrepiform meristele of the petiole of Loxsoma. This type is to be found in Trichomanes apiifolium, Presl, where not only the xylem-strand, but also the outline of the meristele itself, has the form of a horseshoe or arch, and further, the ends of the arms of the xylem are prolonged into incurved 'hooks' precisely as in Loxsoma. It also appears that there is a protoxylem-group in the bay of each hook, and probably one in the middle of the curved region. Trichomanes Prieurii, $\mathrm{Kz}$., is also a most instructive type; for here, although the xylem-strand exhibits the same form as in T. apiifolium, sometimes with two protoxylem-groups on the curved region, the outline of the meristele no longer follows that of the xylem, but is approximately reniform. This state of affairs will permit of a fairly close comparison with the meristele in Loxsoma at a point near the top of the rachis, where it becomes diminished in size and simplified in form (cf. Fig. $7, c$ ), and especially so since this particular Trichomanes also presents cavityparenchyma and fibrous elements, some of which may represent sclerosed sieve-tubes. Granted these two examples, the petiolar strands of many other species fall into line as a series of progressive simplifications of the horseshoe design in accordance with the diminution in their size. Thus, in those of the type of Trichomanes scandens, L., the hooks at the ends of the arms of the xylem have practically disappeared, leaving a $\Lambda$ or crescent-shaped strand with a protoxylem at the end of each arm and one median dorsal. The outline of the meristele itself is now circular. By the disappearance of the median protoxylem a still simpler type is produced, 
such as in the stouter Hymenophyllums, where the xylemstrand has the form of a crescent with a protoxylem-group at either end. Judging from a diagram by Prantl, T. Bancroftii is somewhat after the same type, with the meristele flattened out, and the hooks of the xylem-band persistent, but closely adpressed to the curved position. According to the same authority the xylem-strand of the petiolar meristele of $T$. tanaicum also has the form of a crescent with two protoxylems, one at either end, but with the phloem entirely confined to the abaxial surface of the xylem, the adaxial concavity being occupied by a group of fibrous elements.

There are a number of points in the anatomy of the Schizaeaceae again that may be used for comparison with Loxsoma, but none are of sufficient weight to constitute a close relationship. For instance, there is at least one species of Aneimia (A. Mexicana), in which a closed vascular ring is found in the stem. Through the kindness of Mr. Boodle, who is about to publish an account of the anatomy of this Order, I was enabled to examine a section of this plant, but there is little to be found in the exiguous vascular strand of the Aneimia that may be compared with the solenostele of Loxsoma save the bare form alone. It appeared to me that the vascular tissue of the Aneimia had undergone a great amount of reduction, in which opinion, I believe, Mr. Boodle also concurs. A much more striking analogy between Loxsoma and the Schizaeaceae is to be found in the exarch evenly distributed protoxylem-elements of the stem of Schizaea and Lygodium; further, in Schizaea, and possibly also in Lygodium, the elements appear to be all scalariform. The petiole of Aneimia (A. Phyllitidis) exhibits again an almost typical example of a hippocrepiform meristele with cavity-parenchyma and sclerosed sieve-tubes. Too little is known about the detailed anatomy of the Schizaeaceae as a whole to drive the comparison further. 


\section{SUMMARY.}

To sum up shortly, the principal features of the anatomy of Loxsoma and the conclusions resulting from their consideration may be stated as follows:-

I. The stem is typically solenostelic.

2. A single vascular strand is given off to each petiole having the form of a horseshoe, the xylem being of the same form, and hooked at the ends.

3. In the stem the protoxylem-elements, which are all scalariform, are not localized into definite groups, but are distributed around the external periphery of the solenostele.

4. In the petiole the protoxylem-elements, which are spiral and annular, are collected into definite endarch groups, but they are not continued down into the solenostele of the stem.

5. Parenchymatous islets are found in the sclerenchyma of the stem, and intercellular rodlets in the tissues of both stem and leaf.

6. Sclerosed fibres and cavity-parenchyma are present in the vascular strand of the petiole.

7. By its anatomy Loxsoma is more nearly related to the Dennstaedtiinae and the solenostelic Polypodiaceae than to any other family of Ferns, although affinities of a more remote nature to the Gleicheniacere, Schizeaceae, and Hymenophyllaceae are also indicated.

\section{CONCLUSION.}

In reviewing the anatomy of a number of Fern-petioles I have been greatly impressed by the fact that the plan of the vascular arrangement in the petiole is almost invariably referable to a single universal design, that which I have described as resembling a horseshoe. So much, indeed, is this the case that I have been led to regard it, with some notable exceptions (Lygodium, Schizaea, Marattiaceae, \&c.), as fundamentally typical for the Filicales. In many cases, of course, the 
original design has become more or less masked by the splitting up of the horseshoe into a number of separate portions, which portions may subsequently fuse or anastomose with each other in different ways; yet it is rarely very difficult to trace back such arrangements to the typical scheme. I lay some stress upon this point because, in the Ferns, where such a continuity of design is apparent, I am inclined to regard the modifications in the structure of the leaf-trace as being in a manner complementary to those of the stelic system of the stem, and taken together as presenting material which deserves very careful consideration in discussing the relationships of the plants themselves. I believe that the simplest form of this general design (an undivided horseshoe such as in Loxsoma) may be regarded with tolerable safety as being relatively primitive, and that therefore its occurrence together with a primitive stem-anatomy may be used as additional evidence of much weight regarding the relative position of the plant as a whole.

Finally, I cannot refrain from referring to one other point which the study of Loxsoma forcibly accentuates, and that is, the general similarity that exists between the anatomy of the solenostelic Ferns and that of Marsilea. Allowing for a certain amount of simplification due to a water-habitat, Marsilea differs from them in no essential feature, neither in the structure of the solenostele, the departure of the leaf-trace, nor in the form and structure of the latter. As regards the leaf-trace, it is almost a facsimile of the petiolar meristele of Loxsoma when reduced in size far up the rachis (Fig. 10, d). Cavity-parenchyma is present, and the sievetubes in the deep bay opposite the median protoxylem, although they are not exactly sclerosed, are exceptionally thick-walled. A similar parallelism is found in other details, such as the splitting of the scalariform tracheides along a spiral line when macerated, \&c. The leaf-trace protoxylems do not appear to be prolonged down into the stem. In the stems of species with a tolerably stout xylem-ring there do not seem to be any localized protoxylems, although the smaller 


\title{
Anatomy of Solenostelic Ferns: I. Loxsoma. 97
}

elements are found towards the external periphery. Russow also comments upon the absence, or at any rate the extreme rarity of spiral or annular elements in the stem. These features are quoted with the intention of pointing out the general anatomical similarity of Marsilea to a simple plan of Fern-anatomy, but without drawing the comparison definitely with any individual genus or order.

I take this opportunity to express my gratitude to Professor Bower for the interest he has taken in my work, and for the valuable advice and assistance he has given me in the construction of this paper.

I have also to thank Dr. W. H. Lang for useful advice upon many points.

\section{EXPLANATION OF THE FIGURES IN PLATE III,}

\author{
Illustrating Mr. Gwynne-Vaughan's paper on Loxsoma.
}

Figs. $1,2,3,6,8$, and 9 , are from photographs; a more or less under-exposed print was taken, and this was accentuated with a pencil; Figs. 5, IO, I I, and I2, are camera lucida diagrams ; Figs. 4 and 7 are diagrams. The following lettering is used throughout : $e$, external endodermis ; $e^{\prime}$, internal endodermis; $P$, external pericycle; $P^{\prime}$, internal pericycle; $p h$, external phloem; $p h^{\prime}$, internal phloem; $p p h$, external protophloem ; $p p h^{\prime}$, internal protophloem; $x$, xylem; prx, protoxylem.

Fig. I. Portion of a transverse section of an internode of the rhizome: ss, solenostele; at the zones marked $(x)$ the ground-tissue is more sclerotic than elsewhere. The solenostele is preparing to give off a leaf-trace on the left. $\times$ I 2 .

Fig. 2. Portion of a transverse section of the solenostele: $a, a^{\prime}$, zones of parenchyma intervening between the two endodermal layers $\left(e, e^{\prime}\right)$ and the sclerenchyma of the ground-tissue. $\times \mathrm{r}_{5} \mathrm{O}$.

Fig. 3. Portion of a transverse section of the solenostele towards the apical region of the stem. The xylem is not yet completely differentiated, although the protoxylem elements $(p r x)$ are already well thickened and lignified: $m$, unthickened elements of the metaxylem. $\times$ I 00.

Fig. 4. Diagram showing the form of the vascular system at the nodes of the rhizome : ss, solenostele; $l t$, deparitng leaf-trace; $l g$, leaf-gap. The arrow points towards the apex of the rhizome.

Fig. 5. Transverse section of the petiolar meristele at a point below the middle of the petiole; slightly diagrammatic: $h k$, the hooked ends of the xylem-strand; 
sc. t., sclerosed sieve-tubes; ip, cavity-parenchyma opposite each of the protoxylem-groups. $\times 50$.

Fig. 6. Left-hand corner of Fig. 6 more highly magnified: $h k$, hooked ends of the xylem-strand; sc. $t$., sclerosed sieve-tubes; $l p$, cavity-parenchyma; $p a$, parenchyma-cells among the sclerosed sieve-tubes; $x$. sh., xylem-sheath. At $(\mathrm{x})$ the sclerosed sieve-tubes are seen to be in immediate contact with the tracheides. $\times 260$.

Fig. 7. Diagrammatic transverse sections of the petiolar meristele in different regions of the leaf: $a$, about half-way up the petiole; $b$, just below the insertion of the lowest branch; $c$, about the middle of the branched portion; $d$, near the top of the rachis; $e$, in the principal vein of a leaf-segment. The protoxylemgroups are indicated by black dots.

Fig. 8. Transverse section of the petiolar meristele at about the stage $7, d$, more highly magnified: $s c$. $t$., sclerosed sieve-tubes; $P$, pericycle. Note the disappearance of the hooks at the ends of the xylem-strand. $\times 180$.

Fig. 9. A scalariform tracheide after maceration in caustic potash. It becomes unrolled into a spiral ribbon bearing several bars of thickening in its breadth. $\times 260$.

Fig. Iо. Two of the fibrous elements of the petiolar meristele (sclerosed sievetubes) in longitudinal section. $x$ about 400 .

Fig. II. Cells of the cavity-parenchyma: $a$, an older, $b$, a younger stage. $x$ about 300 .

Fig. 12. Transverse section of a stoma. Intercellular rodlets are found in the substomatal cavity. $\times$ about 500 . 

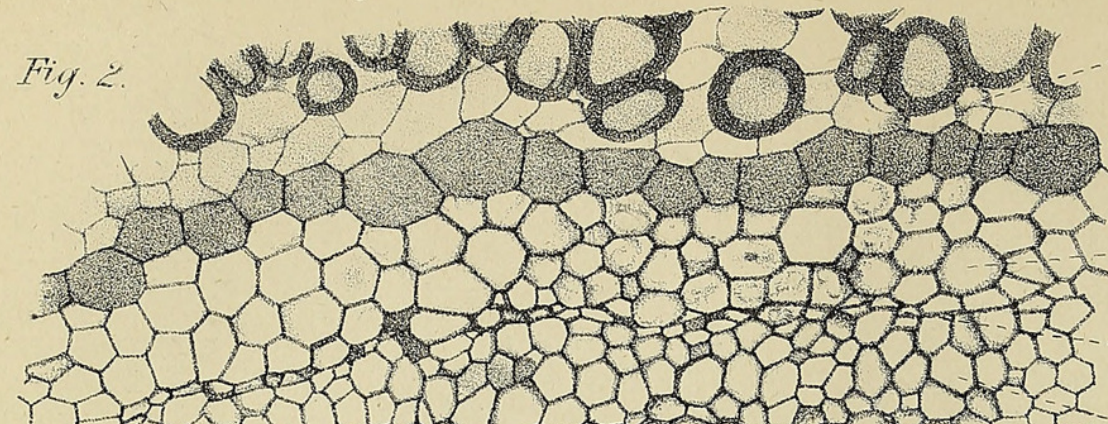

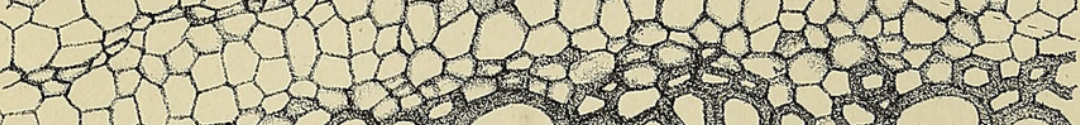
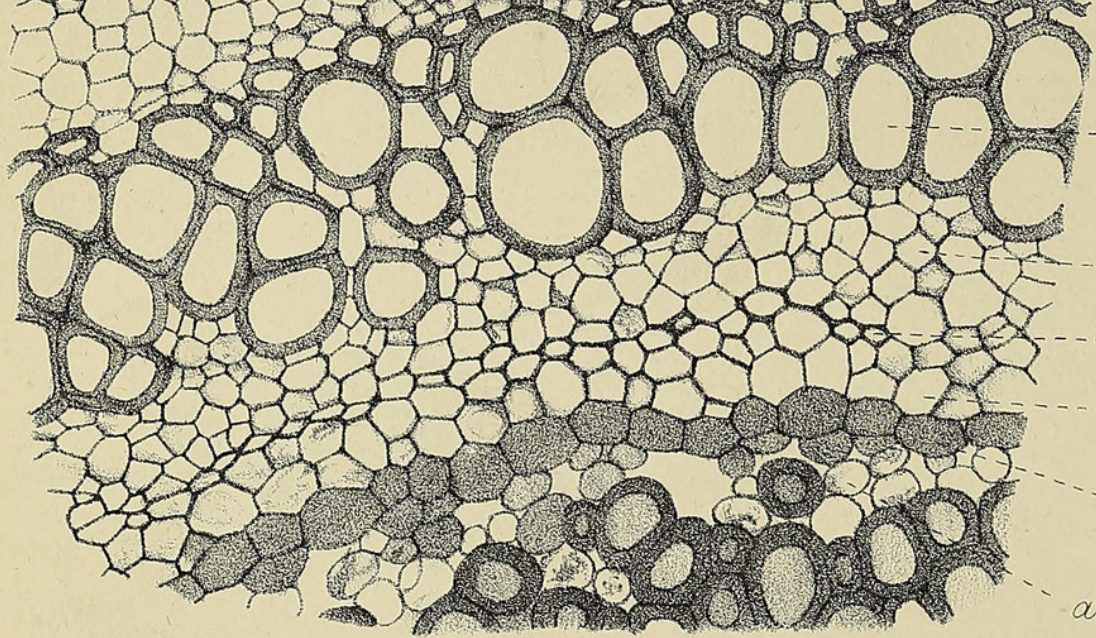

\section{$P^{1}$}

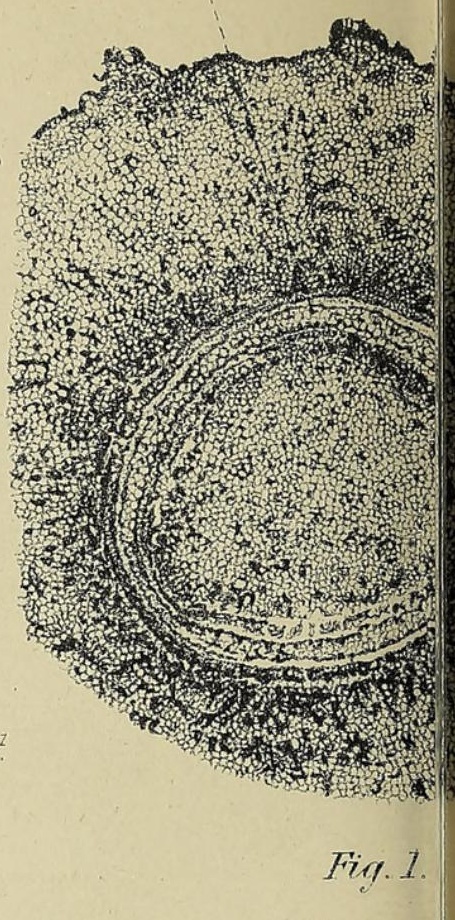

$a^{2}$

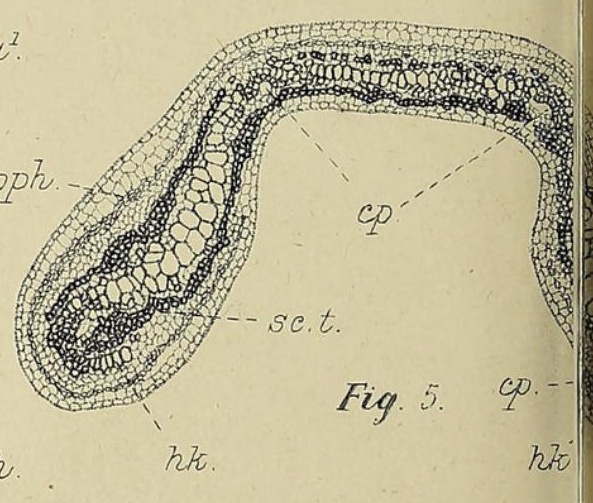

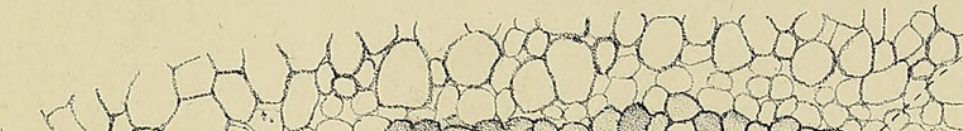
Thenen की

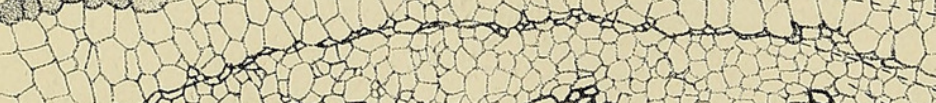

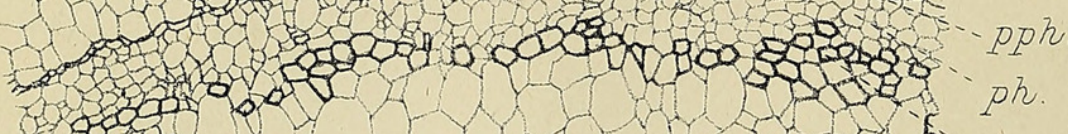
300 D a n a phe

$x=35$ -

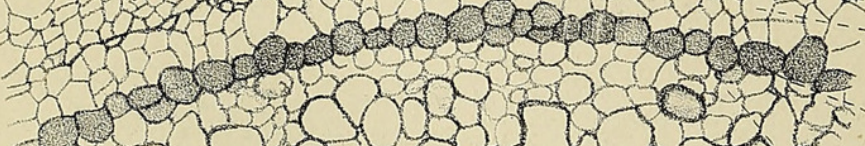
Fig. 3. किती की

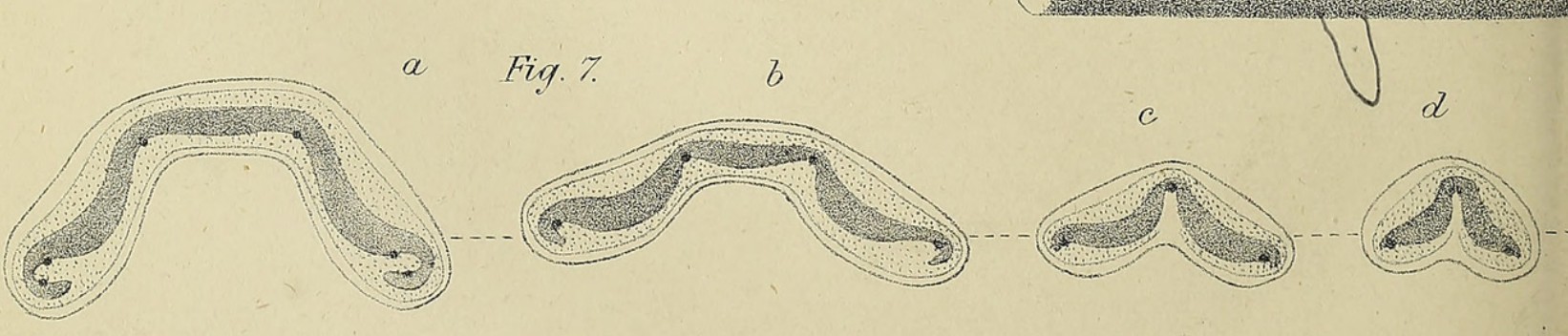


Vol.XV, PL.III.

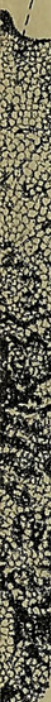

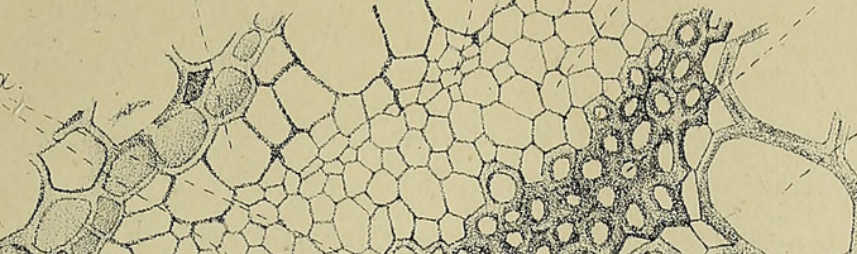

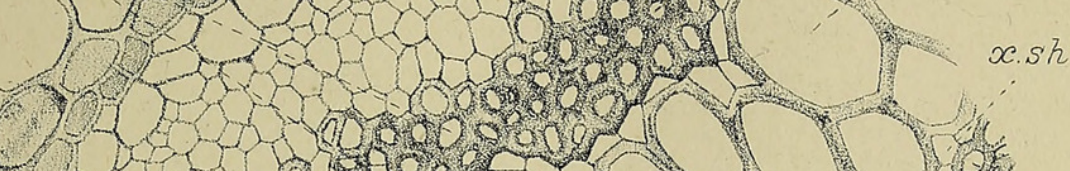

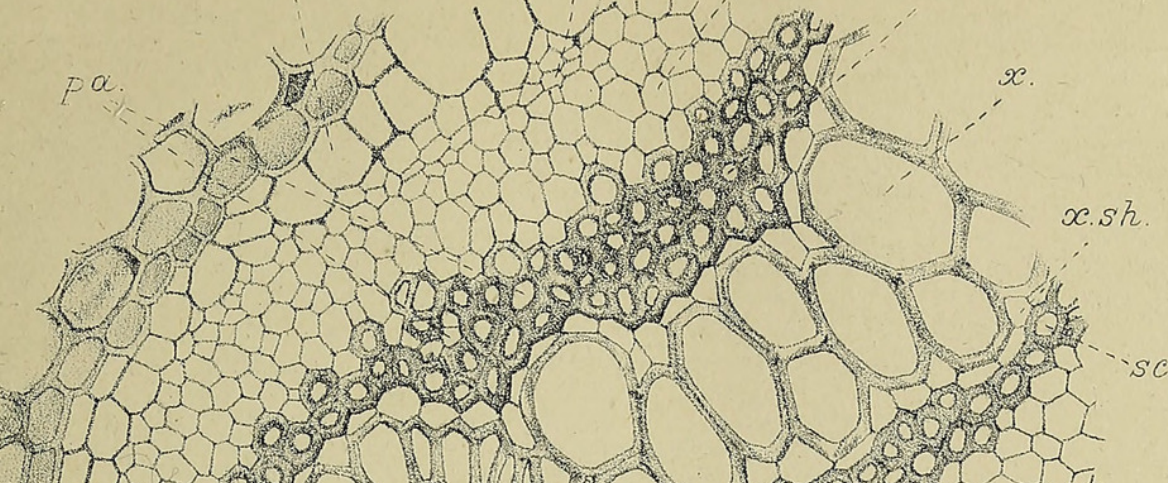<smiles>C1#CC2C#CC1C2</smiles>

s

淛

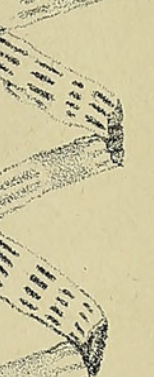

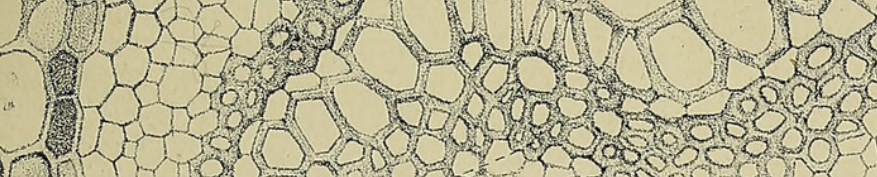

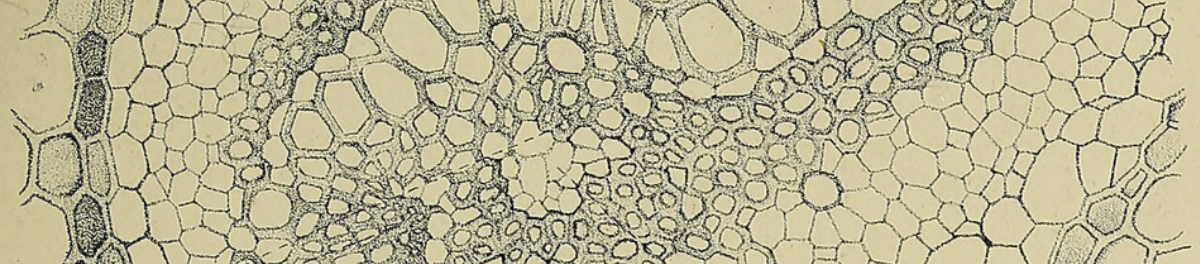

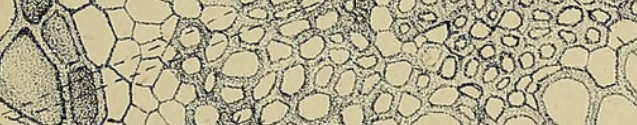

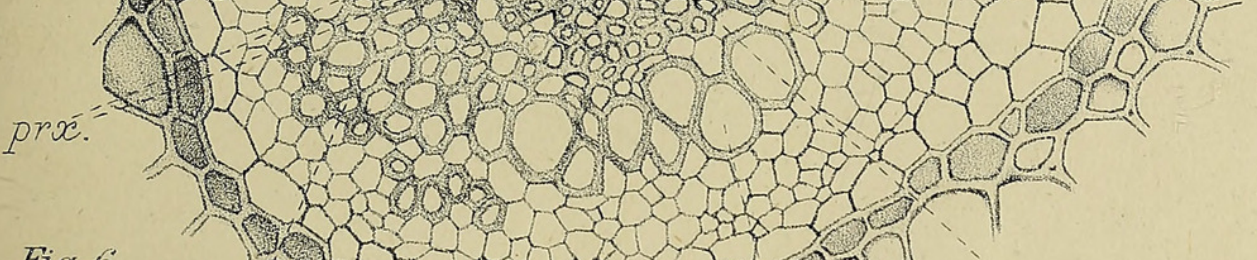

Fig. G.

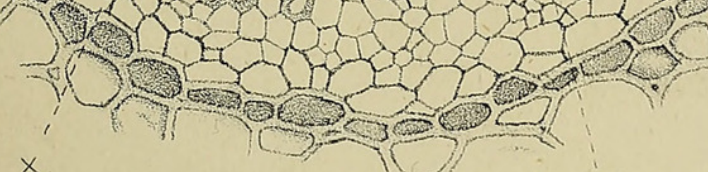

$h k$

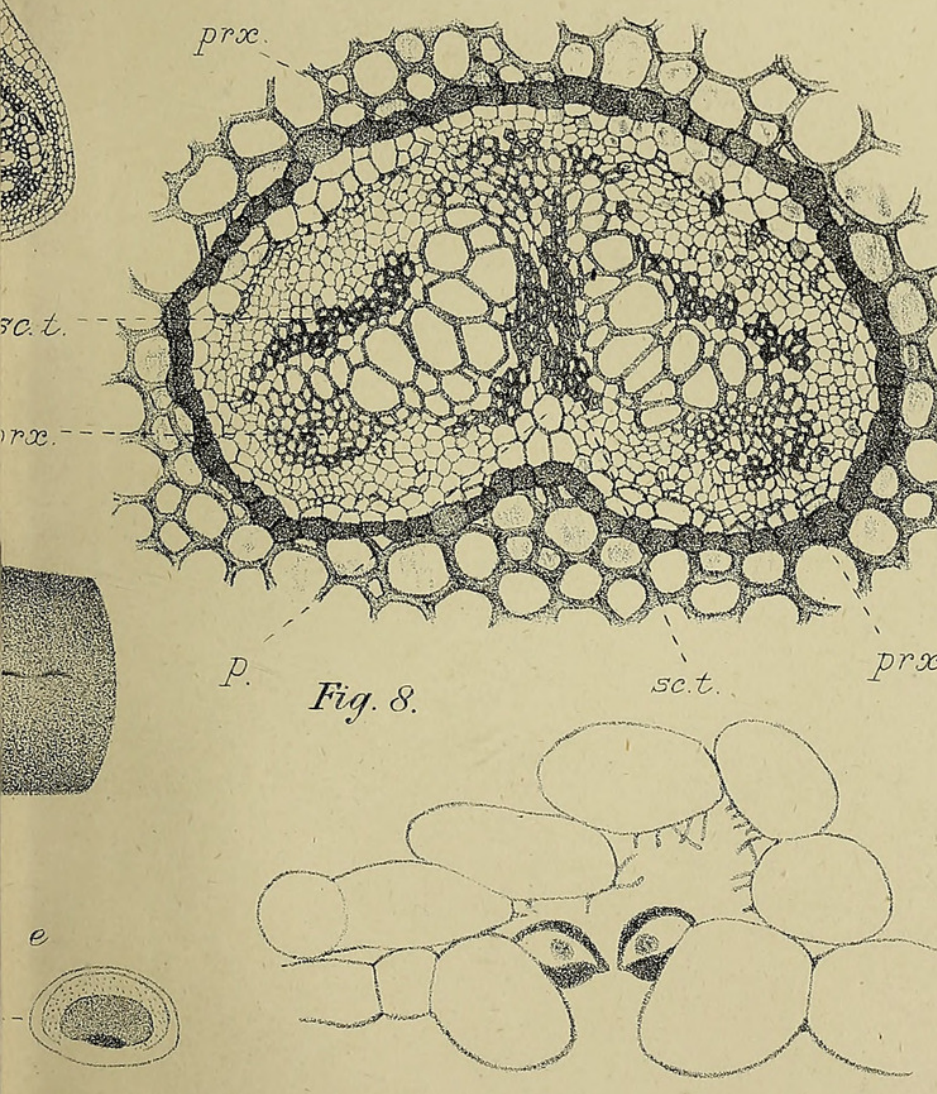

Fig. 9.
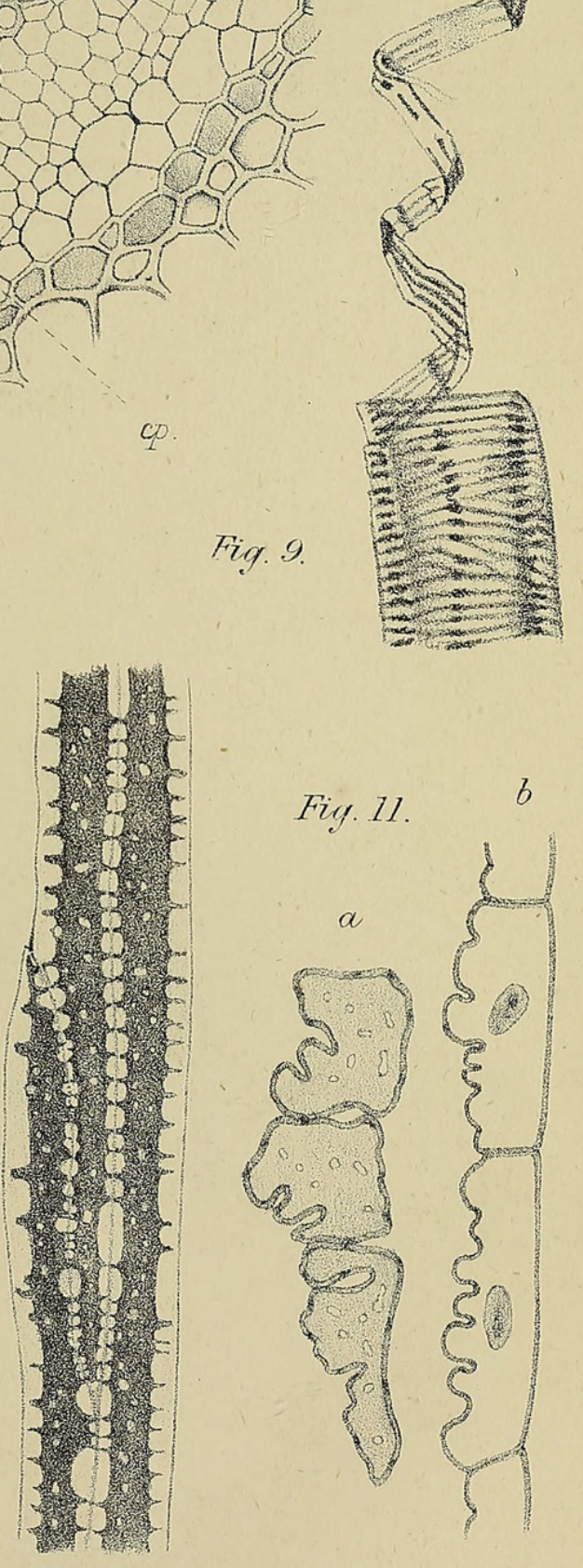

Fig. 12

Fin. 10.

University Press. Oxford 


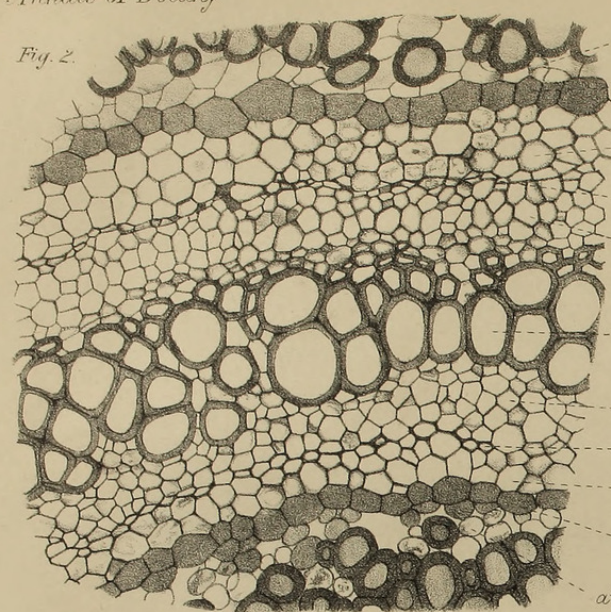

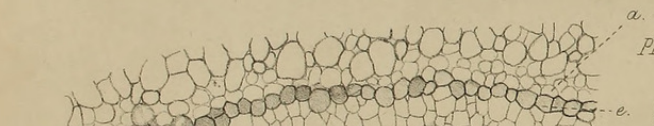
novogaron

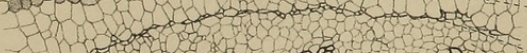

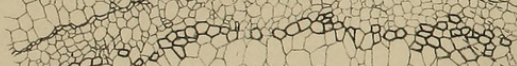
3.

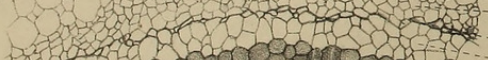

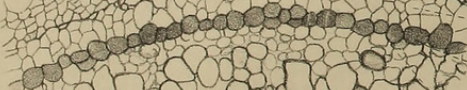
ton
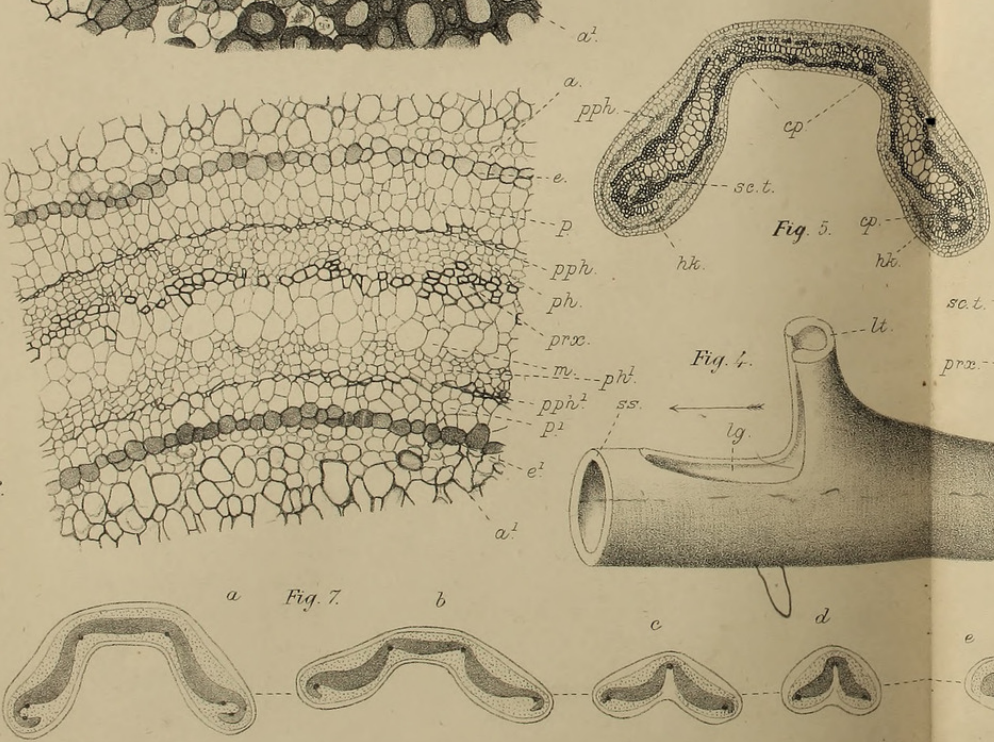

D. T. G-V. Photo at del.

GWYNNE-VAUGHAN - LOXSOMA
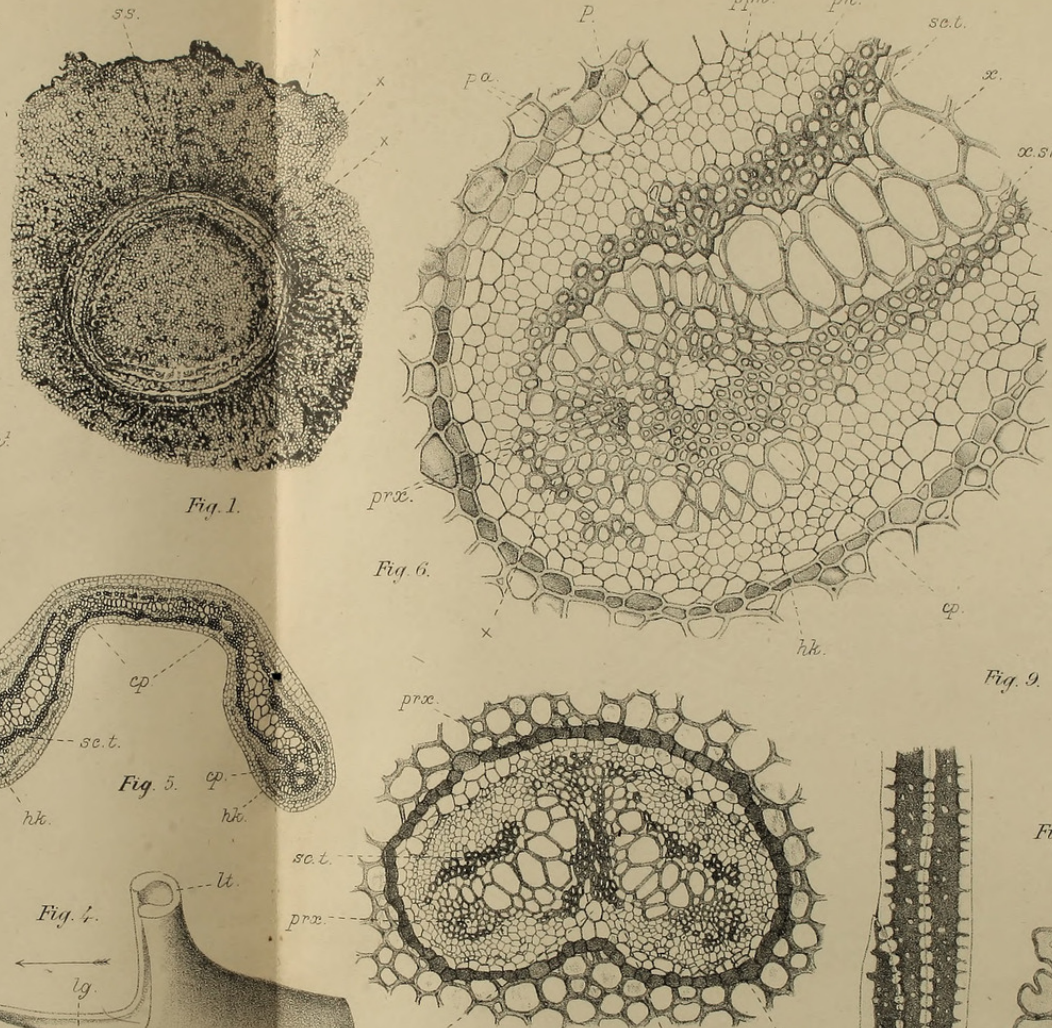

Fig. 8 .

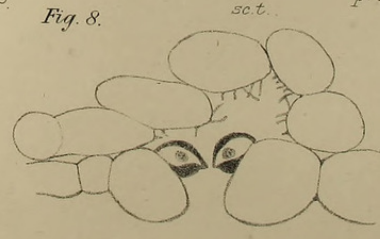

Fig. 12 .

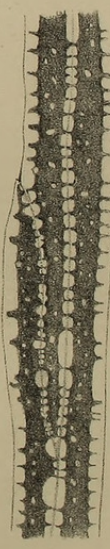

Fig. 9
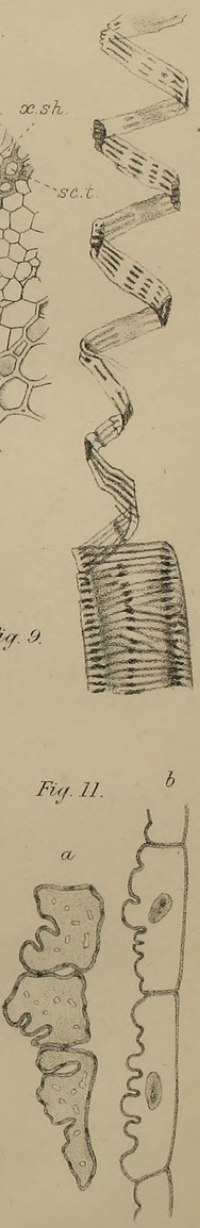


\section{$2 \mathrm{BHL}$ Biodiversity Heritage Library}

Gwynne-Vaughan, D. T. 1901. "Observations on the anatomy of solenostelic ferns. I. Loxsoma." Annals of botany 15, 71-98. https://doi.org/10.1093/oxfordjournals.aob.a088815.

View This Item Online: https://www.biodiversitylibrary.org/item/236929

DOI: https://doi.org/10.1093/oxfordjournals.aob.a088815

Permalink: https://www.biodiversitylibrary.org/partpdf/318611

\section{Holding Institution}

Smithsonian Libraries

\section{Sponsored by}

Biodiversity Heritage Library

\section{Copyright \& Reuse}

Copyright Status: Not in copyright. The BHL knows of no copyright restrictions on this item.

This document was created from content at the Biodiversity Heritage Library, the world's largest open access digital library for biodiversity literature and archives. Visit BHL at https://www.biodiversitylibrary.org. 